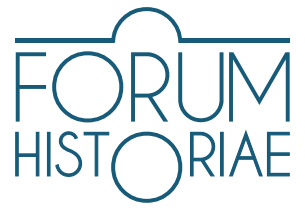

\title{
An Unequal Alliance: Social Scientists as Experts in Socialist Czechoslovakia
}

\author{
Vítězslav Sommer
}

\begin{abstract}
SOMMER, Vítězslav. An Unequal Alliance: Social Scientists as Experts in Socialist Czechoslovakia.

This article examines the role of social scientific expertise in socialist Czechoslovakia. The first section centres on the 1950s, when the new social sciences that helped build the institutions and rules of the new regime were established. The roles of social scientists as experts are analysed during the reform era of the 1960s and the so-called consolidation regime of the 1970s. In the final part of this text, the 1980s are characterised as a period when the unequal alliance of the social sciences and the socialist state fell apart. The article demonstrates that studying the relationship of state policies towards social scientific expertise deepens our understanding of state socialist rule. Scrutinising the responses to demands imposed by the state and the Communist Party of Czechoslovakia (KSČ) on academia and expertise provides a fresh perspective on the attitudes of the educated middle class towards socialism as a political project and an everyday reality.
\end{abstract}

Keywords: Czechoslovakia 1948-1989, Cold War, State Socialism, History of expertise

DOI: https://doi.org/10.31577/forhist.2021.15.2.5

$\mathrm{I}_{\mathrm{f}}^{\mathrm{n}}$ n the summer of 1945, head of the Office of Scientific Research and Development from 1941 to 1947 and science advisor Vannevar Bush submitted a report entitled Science: The Endless Frontier to American President Harry S. Truman. He proposed that the state invest more funding into science research and projects, take greater responsibility for the development of education and place more emphasis on putting the results of scientific research into practice. Bush saw overcoming the boundaries of human knowledge as not only a necessary condition for solving the problems of American society, but also as a new source of discovery and entrepreneurship, something the United States of America (USA) was well-known for. He insisted to the president:

The pioneer spirit is still vigorous within this nation. Science offers a largely unexplored hinterland for the pioneer who has the tools for his task. The rewards of such exploration both for the Nation and the individual are great. Scientific progress is one essential key to our security as a nation, to our better health, to more jobs, to a higher standard of living, and to our cultural progress. ${ }^{1}$

The report was a foundational document of US science policy in the post-war period.

The alliance between the state and science in the USA during the Cold War has been processed in great detail by historians, who have shown that the creation of research

This work was supported by the European Regional Development Fund project: "Creativity and Adaptability as Conditions of the Success of Europe in an Interrelated World" (reg. no.: CZ.02.1.01/0.0/0.0/16_019/00007 34).

1 BUSH, Vannevar. Science, The Endless Frontier: A Report to the President by Vannevar Bush, Director of the Office of Scientific Research and Development, July 1945. Available on the Internet: https://www.nsf.gov/od/lpa/ nsf50/vbush1945.htm\#transmittal 
bases was meant as a means of strengthening national security, especially in light of the superpower's rivalry with the Soviet Union (USSR). ${ }^{2}$ Generous financial resources flowed into American universities and other research institutions from the budgets of security forces in particular. The aim was not only the development of technologies useful for the defence industry, but also control systems, organisational technologies and theoretical concepts. They were to help the state with economic planning, strategic decision-making and development policies in the Global South. "Cold War social science" is responsible for cybernetics, organisational science, systems theory, game theory, rational choice theory, communications theory and modernisation theory. ${ }^{4}$ Social scientists created "social technologies", intended to govern the state, the economy and society as a whole.

Social scientific knowledge also found an application in solving domestic problems of the USA such as poverty, race segregation and the urban crisis. The creation of a welfare state, economic and urban planning, and social engineering were areas where the social sciences found significant utility. This fruitful partnership of the state and academia suffered, however, in the 1960s when the post-war liberal consensus, including faith in the unlimited possibilities of policies based on scientific knowledge, fell apart. The involvement of scholars in the Vietnam War and other foreign policy activities was condemned, not only by a sceptical public, but even the academic community itself. ${ }^{6}$ The counterculture criticised the post-war technocracy and its blind faith in Western scientific rationality. Moreover, the economic crisis of the 1970s combined with growing environmental issues dealt yet another blow to the once unquestioned partnership between the state and science.

The study of similar questions in the context of state socialism puts a difficult task before the historian. Although sizable attention has been paid to the history of science in the socalled Eastern Bloc, particularly to the history of institutions and the ideological control of research, considerable gaps still exist in the understanding of interactions between the state and social sciences under socialist dictatorships. ${ }^{7}$ The idea of a partisanship of knowl-

2 ERICKSON, Paul - KLEIN, Judy L. - DASTON, Lorraine et al. How Reason Almost Lost Its Mind: The Strange Career of Cold War Rationality. Chicago : The University of Chicago Press, 2013; SOLOVEY, Mark - CRAVENS, Hamilton (eds.) Cold War Social Science: Knowledge Production, Liberal Democracy, and Human Nature. New York : Palgrave Macmillan, 2012; SOLOVEY, Mark. Shaky Foundations: The Politics-Patronage-Social Science Nexus in Cold War America. New Brunswick, N.J.; London : Rutgers University Press, 2013; SOLOVEY, Mark. Social Science for What? Battles over Public Funding for the "Other Sciences" at the National Science Foundation. Cambridge, MA : MIT Press 2020.

3 DAYE, Christian. Experts, Social Scientists, and Techniques of Prognosis in Cold War America. Cham : Palgrave Macmillan, 2020; LORENZINI, Sara. Global Development: A Cold War History. Princeton : Princeton University Press, 2019; ANDERSSON Jenny. The Future of the World: Futurology, Futurists, and the Struggle for the Post Cold War Imagination. Oxford : Oxford University Press, 2018.

4 AMADAE, Sonja M. Rationalizing Capitalist Democracy: The Cold War Origins of Rational Choice Liberalism. Chicago : The University of Chicago Press, 2003; AMADAE, Sonja M. Prisoners of Reason: Game Theory and Neoliberal Political Economy. New York: Cambridge University Press, 2016; GILMAN, Nils. Mandarins of the Future: Modernization Theory in Cold War America. Baltimore : Johns Hopkins University Press, 2003; MIROWSKI, Philip. Machine Dreams: Economics Becomes a Cyborg Science. Cambridge : Cambridge University Press, 2002.

5 HEYCK, Hunter. Age of System: Understanding the Development of Modern Social Science. Baltimore : Johns Hopkins University Press, 2015; LIGHT Jennifer S. From Warfare to Welfare: Defense Intellectuals and Urban Problems in Cold War America. Baltimore : Johns Hopkins University Press, 2003.

6 Regarding the problematic relations between Cold War states and academia, see SOLOVEY, Mark. Project Camelot and the 1960s Epistemological Revolution: Rethinking the Politics-patronage-social Science Nexus. In Social Studies of Science, 2001, Vol. 31, No. 2, p. 171-206; KAPLAN, Fred. The Wizards of Armageddon. Stanford : Stanford University Press, 1991; ROBIN, Ron. The Making of the Cold War Enemy: Culture and Politics in the MilitaryIntellectual Complex. Princeton : Princeton University Press, 2003. For criticism of the involvement of experts, intellectuals and academic institutions in American foreign policy, see CHOMSKY, Noam - KATZNELSON, Ira - LEWONTIN, R. C. et al. The Cold War \& The University: Toward an Intellectual History of the Post-war Era. New York : The New Press, 1997.

7 CALDWELL, Peter C. Dictatorship, State Planning, and Social Theory in the German Democratic Republic. New 
edge production was the foundation of the Marxist-Leninist theory of knowledge, which influenced the social sciences and humanities for a significant period of time. Socialist countries built research infrastructure, but at the same time enforced political control of scholarship and the state investment came with obstructions, particularly through repeated political interference into the academic community. Furthermore, experts' activities were influenced by the simultaneous existence of state and party apparatuses. With reference to the definition used by Gil Eyal, who understands "expertise" as the transfer of scientific knowledge from the academic sphere into politics, experts during the time of state socialism found themselves in an extremely complicated situation, from an ideological perspective and also from an institutional point of view. ${ }^{8}$ Aside from academic or expert institutions and state authorities (e.g. ministries, the planning organisation, state-owned enterprises), the pervasive party apparatus also influenced research and expertise substantially. This involved the complicated interconnection of institutions and power hierarchies with formal and informal rules.

This article examines the role of social science experts in Czechoslovakia in the building and governing of the bourgeoning socialist state. ${ }^{9}$ The first part focuses on the 1950s, when the new social sciences that helped built institutions and establish the rules of the new regime were founded. In the second part of the article, the roles of the social sciences in the reform era of the 1960s are examined. This period is characterised not only as an era of critical reflection on Stalinism, but also one of experimentation and innovation.

Next is a look at the relationship between the socialist state and the social sciences in the 1970s, when state policies, ostensibly based on scientific knowledge and expertise, maintained existing institutions and power relations through centralised party control. The social sciences were intended to reinforce the technocratic character of the so-called consolidation regime.

In the final part, the 1980s are defined as the period when the unequal alliance of the social sciences and the socialist state dissolved. While political elites mobilised the social sciences to rescue socialism, general scepticism and an effort to emancipate themselves from the hands of a centralised and bureaucratic state predominated on the side of scholars and experts. Ultimately, it was the social scientists who contributed most to the search for developmental alternatives that went beyond the boundaries of socialism.

This article endeavours to show that understanding the relationship of state policy towards the social sciences provides more general knowledge about the history of socialist rule.

York : Cambridge University Press, 2003; GEROVITCH, Slava. From Newspeak to Cyberspeak: History of Soviet Cybernetics. Cambridge, MA : The MIT Press, 2002; BOCKMAN, Johanna K. Markets in the Name of Socialism: Left-Wing Origins of Neoliberalism. Stanford : Stanford University Press, 2011; RINDZEVIČIŪTĖ, Eglè. The Power of Systems: How Policy Sciences Opened Up the Cold War World. Ithaca, NY : Cornell University Press, 2016.

8 EYAL, Gil. The Crisis of Expertise. Cambridge : Polity Press, 2019, pp. 7-8. Eyal characterises expertise as the interface between academia, politics and legislation, where expert activities take place. Although expertise uses the arguments and methods of scientific research and many experts actually operate within academia, it moves in a faster timeline. Expertise respects the different pace of academic research and politics, mediates their mutual communication and must be relevant in both spheres.

9 This article summarises the outcomes of my research on expertise in the era of Czechoslovak state socialism. This research is presented most comprehensively, supplemented by Matěj Spurný and Jaromír Mrňka, in SOMMER, Vítězslav a kol. Řídit socialismus jako firmu: technokratické vládnutí v Československu, 1956-1989. Praha : Ústav pro soudobé dějiny AV ČR; NLN, 2019. This article builds mainly on my first attempt at formulating the developmental tendencies of expert governance in socialist Czechoslovakia in the article SOMMER, Vítězslav. Towards the Expert Governance: Social Scientific Expertise and the Socialist State in Czechoslovakia 1950s-1980s. In Serendipities: Journal for the Sociology and History of the Social Sciences, 2016, Vol. 1, No. 2, pp. 138-157. 
Additionally, scrutinising responses to the demands imposed by the state and the Communist Party of Czechoslovakia (KSČ) on academia and expertise provides new insight into the attitudes of the educated middle class towards socialism as a political project and an everyday reality.

\section{Rules, Apparatuses and Institutions (1950s)}

The Communist Party's seizure of power in February 1948 changed the institutional foundation and political function of the social sciences and humanities in Czechoslovakia. High Stalinism, which lasted from 1949 to 1953, called for the establishment of new social sciences and a strengthening of their partisanship. Political elites and academic functionaries sought to turn the social sciences into an "active superstructure" that would contribute to building socialism..$^{10}$ Stalin's work The Economic Problems of Socialism in the USSR (1951) characterised the study of society as a discovery of the laws of social and economic development. The task of the social sciences here was to help the Communist Party through the discovery and description of these laws. ${ }^{11}$ If positivist "bourgeois science" professed the ideal of objectivity, the truth of socialist scholarship rested in the scholars' affiliation with the revolutionary party, which was carrying out an objective, and hence, the true laws of history. Therefore, the social sciences were forced to submit to the demands of party politics.

Mobilisation of the social sciences for the needs of the state, a common phenomenon of the Cold War, was manifested within Czechoslovakia through a significant ideological and institutional reconstruction. The existing conceptual frameworks of individual disciplines were shattered in the name of Marxism-Leninism, and so it is possible to speak of an effort to "Sovietise" the social sciences by applying Soviet Marxism-Leninism as a universal theory. ${ }^{12}$ The ambition to create socialist social sciences and humanities was also reflected in the reconstruction of an institutional base. One immediate consequence of the communists coming to power was a purge of personnel, which despite the preservation of a certain continuity with the previous period, in some fields in particular it created not only new academic elites, but also a new academic and expert milieu. Institutional reconstruction, including an effort to apply Soviet models of research organisation in Czechoslovakia, followed such repressive interventions. ${ }^{13}$ The buttress of basic research was to be the Czechoslovak Academy of Sciences (ČSAV) and the Slovak Academy of Sciences (SAV), which was founded in $1953 .{ }^{14}$

10 On the relationship between partisanship and knowledge production, see SOMMER, Vítězslav. Angažované dějepisectví: Stranická historiografie mezi stalinismem a reformním komunismem (1950-1970). Praha : Nakladatelství Lidové noviny; Filozofická fakulta Univerzity Karlovy, 2011, pp. 99-112.

11 STALIN, Josif Vissarionovich. Economic Problems of Socialism in the USSR. Peking : Foreign Language Press, 1972.

12 For a case study of Czech historiography, see JIROUŠEK, Bohumil. Časopis „Sovětská věda - Historie“ jako „vzor“ historikovy práce a nástroj ideologizace vědy. In Soudobé dějiny, 2013, Vol. 20, No. 3, pp. 379-398.

13 Forms of "Sovietisation" of universities in the region, see CONNELLY, John. Captive University: The Sovietization of East German, Czech, and Polish Higher Education, 1945-1956. Chapel Hill : University of North Carolina Press, 2000; and JAREŠ, Jakub - FRANC, Martin a kol. Mezi konkurencí a spoluprací: Univerzita Karlova a Československá akademie véd 1945-1969. Praha : Univerzita Karlova, Karolinum, 2018, (particularly chapters III and IV).

14 For the founding of the ČSAV, see JŮNOVÁ-MACKOVÁ, Adéla. Vládní komise pro vybudování Akademie věd. In FRANC, Martin - DVOŘÁČKOVÁ, Věra a kol. Dějiny Československé akademie věd. I, 1952-1962. Praha : Academia, 2019, pp. 106-137 and JŮNOVÁ-MACKOVÁ, Adéla. Vznik ČSAV a její první zákon, osud předchůdcovských institucí, kontinuita a diskontinuita. In FRANC - DVOŘÁČKOVÁ a kol. 2019, pp. 170-179. The founding of the Slovak Academy of Sciences was treated by HUDEK, Adam. Slovenská akadémia vied a umení v rokoch 19451952. Prerod SAVU do Slovenskej akadémie vied. In KOVÁČ, Dušan a kol. Dejiny Slovenskej akadémie vied. 
The social sciences were then assigned to these new institutions. ${ }^{15}$ The structure of the ČSAV in April 1954 included a philosophical-historical department comprised of three institutes; Historical, Archaeological and Ethnography and Folklore studies, and four cabinets, which were responsible for research on philosophy, art history and theory, pedagogical sciences and the work of historian and musical theorist Zdeňek Nejedlý, a communist intellectual, politician and the first president of the ČSAV. ${ }^{16}$ The economics and law department was composed of the Economic Institute of the ČSAV, supplemented by cabinets of the history of the state and law, international law and the state and law in the USSR. ${ }^{17}$ Five institutes and two cabinets comprised the language and literature department: the Institute for Czech Language, the Institute for Czech Literature, the Slavic Institute, the Institute of Russian Language, the Literature and History of the USSR (later the Czechoslovak-Soviet Institute) and the Oriental Institute, as well as the Cabinet for Modern Philology and a cabinet for the study of Greek, Roman and Latin. ${ }^{18}$ The ČSAV included traditional disciplines, such as historiography, linguistics or ethnography, and at the same time institutionalised the ideologically important fields of research that were considered key for building socialism, such as economics and legal science. During the 1950s, this institutional structure expanded and then stabilised. In 1956, there was an independent Institute of Law, later the Institute of the State and Law, in which the previously independent legal sciences cabinets were housed. ${ }^{19}$ Two years later, the Institute of Philosophy came into existence, soon becoming the centre of Marxist thought and holding theoretical discussions on the origins of reform communism at the end of the 1950s and beginning of the 1960s. ${ }^{20}$

Stalinism demanded from the social sciences an unequivocal acceptance of Marxism-Leninism, including a retrospective confirmation of its accuracy through empirical research. The social sciences and humanities thus fulfilled a propagandistic function, serving as theoretical support for Stalinist policies. When Czechoslovak socialism experienced economic and political problems in 1953, they equally fell on the social sciences and as soon as criticism of Stalinism began, the social sciences lost the ground beneath their feet. If their only function was to promote and theoretically justify party policies, the end of Stalinism destroyed any legitimacy they had. The start of de-Stalinization was a major turning point for the social sciences, which began to move away from a propaganda based role to an emphasis on the expert positions.

The social sciences now shifted to a different model of politicisation, which was already in effect on the opposite side of the "Iron Curtain". The violent and chaotic policies of Stalinism would be replaced by governance based on scientific knowledge, advanced organisational

Bratislava : VEDA, 2013, pp. 69-86; and HUDEK, Adam - KLAČKA, Jozef. Vznik Slovenskej akadémie vied. In KOVÁČ a kol. 2013, pp. 89-105. The mutual relationship of both institutions in the period is mapped by HUDEK, Adam. ČSAV a SAV 1952-1956. In FRANC - DVOŘÁCKOVÁ a kol. 2019, p. 278-291.

15 The passage on the institutional anchoring and research focus of the social sciences and humanities in the 1950s comes from SOMMER, Vítězslav. Humanitní a společenské vědy v ČSAV. In FRANC - DVOŘÁČKOVÁ a kol. 2019 , p. $580-601$.

16 Cabinets were research units smaller than institutes.

17 The Economics Institute of the ČSAV was founded on 1 January 1954 from the Economics Cabinet of the ČSAV, see KAIGL, Vladimír. O stavu a úkolech československé ekonomické vědy. In Věstník Československé akademie věd, 1954, Vol. 63, No. 1-3, pp. 75-83.

18 III. valné shromáždění Československé akademie věd. In Věstník Československé akademie věd, 1954, Vol. 63, No. 4-6, pp. 207-209.

19 Pracoviště ČSAV k 1. lednu 1956. In Věstník Československé akademie věd, 1956, Vol. 65, No. 1-2, pp. 32-34.

20 For the structure of the ČSAV in 1958, see Sedmé valné shromáždění ČSAV. In Věstník Československé akademie věd, 1958, Vol. 67, No. 4-6, p. 227-229. Regarding the development of the Institute of Philosophy of the ČSAV, see MERVART, Jan. Filosofický ústav ČSAV. In FRANC - DVOR̂ÁČKOVÁ a kol. 2019, pp. 602-613. 
methods and the latest technologies. Khrushchev's programme proclaimed a socialism that was not to be scientific only formally, but scientists and experts would play a central role in shaping the institutions and rules of the socialist state. They were to study society and seek ways to complete the "cultural revolution", with the aim of deepening the socialist character of the social structure, value system and lifestyle. Economists should solve economic problems and seek new approaches to organising and managing central planning at all levels - from the planning centre to the management of work and production in individual enterprises. Examples from legal science, political science and economics show the growing importance of social scientific expertise. ${ }^{21}$

In the mid-1950s, the revolutionary phase of socialism ended and a period of stabilisation began. This meant not only a policy of "raising living standards" and completing the collectivisation of agriculture, but also putting the final touches on socialist legislation and institutions. Economists, legal and political scientists were involved in a process labelled as the "completion of the building of socialism", officially culminating in the adoption of a new constitution in 1960.

Experts endeavoured to describe and explain the political and economic order that emerged in the country after 1948. There was a need to clarify phenomena such as the socialist revolution, the socialist state and the people's democracy. Even though the process of building socialism lay in seemingly unambiguous Marxism-Leninism, the theoretical definitions of the new order were wholly vague. The socialist revolution was the first issue to spark controversy between legal and political scientists. Adopted from the USSR, it offered a scheme of revolutionary processes based on the Soviet experience, however, Czechoslovak development after 1945 urged a different concept. The clash between a binding Soviet theory and the Czechoslovak reality encouraged a new theory for national variants of socialist revolution to be devised.

Discussions about revolution and the socialist state continued throughout the second half of the 1950s and exposed the limits of post-Stalinist social scientific thought. ${ }^{22}$ This became a dispute between believers of the exclusive application of Soviet concepts and those who were trying to create a theory specific to the conditions of Czechoslovakia. ${ }^{23}$ Although the debate took place on a highly abstract level and resulted in schemes for revolutionary developments in socialism and the people's democracy, it did bring some important

21 For a summary of the development of legal thought in Czechoslovakia in the years 1948-1989, see BOBEK, Michal - MOLEK, Pavel - ŠIMÍČEK, Vojtěch. Komunistické právo v Československu: kapitoly z dějin bezpráví. Brno : Masarykova univerzita, Mezinárodní politologický ústav, 2009.

22 For more details on the institutional development and activities of the legal expertise in the given period, see SOMMER Vítězslav. Experti, právo a socialistický stát: Právní věda v ČSAV a její ćinnost v letech 1952 až 1960 . In Soudobé déjiny, 2016, Vol. 23, No. 1-2, pp. 118-136. From the many contributions to the discussion, for example, see the introductory text of the whole debate HOUŠKA, Jiří - KÁRA, Karel. Př́spěvek k otázkám theorie revoluce a státu v zemích lidové demokracie. In Filosofický časopis, 1954, Vol. 2, No. 4, pp. 273-311 and discussions on the socialist revolution and people's democracy by Michal Lakatoš, Ivan Bystřina, Milan Hübl and others published in 1955 in the journal Právník. An important part of the discussion also ran in 1955 at a conference organised on the tenth anniversary of the liberation of Czechoslovakia. See KLIMEŠ, Miloš - KRÁL, Václav - ZACHOVAL, Marcel (eds.) Otázky národní a demokratické revoluce v ČSR. Sborník př́spěvkủ prednesených na konferenci Historického ústavu ČSAV 28. - 30. IV. 1955 v Liblicích. Praha : ČSAV, 1955. Other articles on the revolution, people's democracy and the socialist state came out during the second half of the 1950s in Filosofický časopis, Právník and in Nová mysl, which was the central theoretical journal of the Communist Party of Czechoslovakia.

23 A final round of discussion took place in 1961 at a conference on the role of the social sciences in building socialism and communism. See the articles in HOUŠKA, Jiří (ed.) Základní teoretické otázky výstavby socialismu a komunismu ve světle výsledků společenských věd. Materiály konference o teoretických problémech výstavby socialismu a komunismu konané v Liblicích ve dnech 26. až 29. dubna 1961. Praha : Nakladatelství Československé akademie věd, 1962. 
findings. For one, the argument demonstrated that some experts did respond to local developments and sought to rethink the theoretical framework of socialist statehood, while also staying within the scope of rigid Marxism. Economists reacted to these developments with a debate about ownership, which ran until the end of the 1950s. They aimed to define a socialist concept of ownership that would correspond to the changes that had occurred in the country over the previous decade. ${ }^{24}$ The goal was not only to modify and adapt the existing theory, but also to create a basis for policy making. Theoretical innovation was a prerequisite for including experts in the discussion on reform policies implemented in the 1960s. These debates showed that a tier of experts could be assembled that was not focused on propaganda, but on solving the practical problems associated with governance. ${ }^{25}$

The most affected discipline was economics. Although economists were directly engaged in the introduction of central planning at the turn of the 1940s, the economic failures that followed led not only to their political repression, but also to the building of a new economic scholarship. In the mid-1950s, leading representatives of the ČSAV admitted that the "political economy of socialism" was one of the least developed areas of the social sciences. In April 1956, František Šorm, a biochemist and leading functionary of the ČSAV declared that "Czechoslovak economics is at the beginning of its development" and suffers from a lack of "mature professional staff". ${ }^{26}$ The economy was forced to reckon with the legacy of Stalinist economics and meet the demands placed on it by the troubled centrally-planned economy.

In the mid-1950s, KSČ leadership announced its intention to decentralise planning and make economic management more "scientific". This would lead to the increased qualification of workers, the introduction of computer technologies and the use of new planning methods based on cybernetics. ${ }^{27}$ Economists praised the simplification of planning and a greater independence for enterprises. "Bureaucratic" methods of management were to be replaced by economic management based on expertise and experts would educate managers and develop processes to facilitate the efficient organisation of individual enterprises, and also of the economy as a whole. At the turn of the decade of the 1950s, economists were already working on the first economic reforms and developed teorie rízení - the Czechoslovak equivalent of management studies - performing interdisciplinary research in business management and workforce organisation..$^{28}$

24 Discussions on ownership emerged from an article by economist Čestmír Kožušník. See KOŽUŠNÍK, Čestmír. Vlastnictví a ekonomické vztahy. In Nová mysl, 1959, Vol. 13, No. 7, pp. 693-708. For a summary of Czechoslovak discussions on ownership in socialism, see HORVATH, Julius - SOMMER, Vítězslav. From Nationalization to Privatization. Understanding the Concept of Ownership in Czechoslovakia (1948-1990). In KOVÁCS, János Mátyás (ed.) Populating No Man’s Land: Economic Concepts of Ownership under Communism. Lanham : Lexington Books, 2018, pp. 87-111.

25 In its extreme form, this trend was shown by the Czechoslovak critique of Yugoslav self-management, which clearly aligned with a very statist conception of socialism. It described Yugoslav socialism as an anarchist project and characterised the centralized socialist state as natural and the only possible institutional platform for building a socialist society. See KUČERA, Eduard. K soudobému revizionismu (K praxi a teorii soudobého jugoslávského revizionismu). Praha : Čs. společnost pro šírení politických a vědeckých znalostí, 1960.

26 ŠORM, František. Usnesení strany a vlády a hlavní směry vědecko-výzkumné činnosti. In Věstník Československé akademie věd, 1956, Vol. 65, No. 5-6, pp. 278-299, quote on p. 290.

27 Usnesení celostátní konference Komunistické strany Ceskoslovenska. In Celostátní konference Komunistické strany Československa. Zvláštní číslo Nové mysli, červen 1956. Praha : Rudé právo, 1956, pp. 246-272.

28 The preparation of the first economic reforms at the end of the 1950s was described by economist Kurt Rozsypal in his memoirs: ROZSYPAL, Kurt. Vývoj plánovitého řízení v netržních podmínkách v letech 1953-1964: 
Legal science also assisted in the building of the socialist state, including the writing of a new Czechoslovak constitution, which was adopted in 1960 as the first law of the republic and officially designating Czechoslovakia as a socialist state. Although party leadership labelled the constitution a collective work between the party and the people, the text was in fact prepared by a group of elite legal experts. ${ }^{29}$ This was likewise true of other legislative changes, such as civil law. Legal scholars discussed possible forms of socialist legislation and with the blessing of the KSČ leadership, formulated key legal documents. In this way, the rules by which the socialist state was to function were thus created.

During this period, the foundation was laid for development of a social strata of experts, which was an important component of the professional middle class. In the 1950s, a generation of experts educated after 1948 grew up and they either identified directly with the goal of building a functioning and prosperous socialism, or at least, pragmatically accepted the fact that expert activity is an opportunity to apply their knowledge and skills. At this time, the socialist state further exercised political control over the sciences and expertise, though an extensive research infrastructure was created simultaneously. Along with the ČSAV and universities, this included a growing number of research institutions falling mainly under the control of ministries or affiliated to enterprises. Furthermore, there was an increasing demand for experts directly in practice, as managers for example. This decade of shaping the rules, institutions and apparatuses paved the way for the golden era of experts in the reformist 1960s.

\section{Reflections, Innovations and Experiments (1960s)}

The building of socialism officially culminated in 1960. Though this could have appeared to be a sign of stabilisation after the turmoil of the 1950s, the reality was much more complicated. Half-hearted de-Stalinization revealed new issues and caused another crisis. Czechoslovakia fell into serious economic trouble in the first half of the 1960s, which put the weaknesses of central planning on display and worsened the crisis of communist ideology. Revelations connected with the fall of the "cult of personality" demolished the seemingly robust structure of Marxism-Leninism. A skeleton in the closet from these times was the legacy of political repression in the 1950s, the investigation of which proceeded slowly as party elites tiptoed around the crimes of Stalinism. ${ }^{30}$

A disturbing past was not the only problem. Aside from economic difficulties, there was a whole set of issues that can be summarily referred to as the development strategies

(paměti). Praha : Vysoká škola ekonomická, 1999. Regarding the origin of Czechoslovak management theory, see SOMMER, Vítězslav. Manažerská odysea: Teorie řízení v Československu v padesátých až osmdesátých letech 20. století. In Soudobé dějiny, 2017, Vol. 24, No. 3, pp. 285-310.

29 Regarding the contribution of legal experts in the preparation of the 1960 Constitution, see SOMMER 2016, Experti, pp. 131-135.

30 For the ideological crisis, see KOPEČEK, Michal. Hledání ztraceného smyslu revoluce: zrod a počátky marxistického revizionismu ve střední Evropě 1953-1960. Praha : Argo, 2009; KOLÁ R̆, Pavel. Der Poststalinismus: Ideologie und Utopie einer Epoche. Köln : Böhlau, 2016 a MERVART, Jan - RÜŽIČKA, Jiř́i. „Rehabilitovat Marxe!": československá stranická inteligence a myšlení post-stalinské modernity. Praha : NLN, 2020. Political contexts are mapped out by BARNOVSKÝ, Michal. Prvá vlna destalinizácie a Slovensko: (1953-1957). Brno : Prius, 2002; BLAIVE, Muriel. Promarněná př́ležitost: Československo a rok 1956. Praha : Prostor, 2001; PERNES, Jiř́i. Krize komunistického režimu v Československu v 50. letech 20. století. Brno : CDK, 2008; KAPLAN, Karel. Kronika komunistického Československa. Doba tání 1953-1956. Brno : Barrister \& Principal, 2005; KAPLAN, Karel. Kronika komunistického Československa. Kořeny reformy 1956-1968: společnost a moc. Brno : Společnost pro odbornou literature, Barrister \& Principal, 2008. 
of socialism. This involved the reform of not only central planning, but technological innovations, functions of the political system, a reassessment of the pros and cons of consumer society and the changes in human labour associated with the advent of automation. What's more, control of information and an inflexible ideology resulted in a lack of credible, up-to-date data on the economy and society. In addition to contemplating and implementing development strategies, it was also necessary to develop a functioning empirical analysis of social and economic reality.

Scientists and experts were targeted to undertake these tasks. A reform policy followed the developments of the preceding decade resulting in, for instance, an expansion of research infrastructure including the founding of the ČSAV Institute of Sociology in 1965, which completed the revival of sociology in Czechoslovakia. ${ }^{31}$ Social scientific expertise secured an extensive institutional base with research institutes connected to the government, ministries and enterprises, whose scope was applied research. For example, the Institute of Management (1965) was founded and served under the Czechoslovak government. Its task was training managers and developing the field of management studies. Other institutions focused on urbanism and architecture, research on living standards, population policy, computer technology and cybernetics, and organisational science.

Historiography has thus far mostly examined the elite research teams, which were the expert basis for reform policies. Prestigious expert collectives included the interdisciplinary team of philosopher Radovan Richta, researching the "social and human implications of the scientific and technological revolution", the economic team of Ota Šik preparing economic reform, a team of political scientists and lawyers headed by Zdeněk Mlynár dealing with reconstruction of the political system and a sociological team, led by sociologist Pavel Machonin, studying the social stratification of Czechoslovak society. All were organised on the basis of cooperation between Communist Party leadership and the Czechoslovak Academy of Sciences. ${ }^{32}$ There were plenty more expert groups, tasked with preparing the groundwork for reform policies. In 1968, this institutional base covered topics ranging from the organisation of enterprises through foreign policy, up to the creation of futuristic visions of socialist post-industrialism.

The last item shows that the 1960s saw not only the development of expert institutions, but also the "expertisation" of communist ideology. While references to science in Stalinist ideology were formal and in conflict with crude political interventions into academia, reform communists followed Khrushchev's programme of "scientisation" and turned science, expertise, and technological development into the building blocks

31 For the renewal of sociology in Czechoslovakia, see VOŘÍŠEK, Michael. The reform generation: 1960s Czechoslovak sociology from a comparative perspective. Praha : Kalich, 2012.

32 For the history of interdisciplinary teams and their influence on Czechoslovak reforms in the 1960s in particular, see HOPPE, Jiří et al. „O nový československý model socialismu“: čtyřri interdisciplinární vědecké týmy při $\check{C} S A V$ a UK v 60. letech. Praha : Ústav pro soudobé dějiny AV ČR, 2015; HOPPE, Jiří - SOMMER, Vítězslav. How the "Richta Team" Was Born: The Scientific and Technological Revolution and Political Decision-making in Czechoslovak Reform Communism. In Zeitschrift für Ostmitteleuropa-Forschung / Journal of East Central European Studies, 2020, Vol. 69, No. 4, pp. 495-518; SOMMER Vítězslav. Scientists of the World, Unite!: Radovan Richta's Theory of Scientific and Technological Revolution. In ARONOVA, Elena - TURCHETTI, Simone (eds.) Science Studies during the Cold War and Beyond: Paradigms Defected. New York : Palgrave Macmillan, 2016, pp. 177-204; SUK, Jiří. Veřejné záchodky ze zlata: konflikt mezi komunistickým utopismem a ekonomickou racionalitou v predsrpnovém Československu. Praha : Prostor, 2016; SKILLING, H. Gordon. Czechoslovakia's Interrupted Revolution. Princeton : Princeton University Press, 1976. 
of communist ideology as a way to resolve the theoretical confusion of post-Stalinism. ${ }^{33}$ The resolutions of the 13th Congress of the KSČ (1966) serve as an example, elevating the theory of a "scientific and technological revolution", until then only the subject of academic hypothesis, to the central motif of the party programme. ${ }^{34}$ Similarly, the KSC Action Programme of April 1968, the main political document from the Prague Spring, highlighted scientific knowledge and expertise as prerequisites for the successful transition to a more democratic and prosperous socialism. ${ }^{35}$

Both the establishment of expert institutions and the innovation of communist ideology led to an increased professional and political self-confidence among experts. They viewed the reforms of socialism as a great experiment, reassessing the foundation of party politics. Their political confidence was exhibited through demands for participation in political decision-making and also better remuneration for their work. They called for the introduction of a less egalitarian model of compensation, which would structure income based on education and work performance. ${ }^{36}$ Wages would be incentive and not favour workers at the expense of the intelligentsia. This principle of fair wages based on performance and expertise was a critical reaction to Stalinist workerism. Experts claimed that they not only deserved higher pay, but also greater social prestige and a corresponding position in the power hierarchy. Researchers from the ČSAV, who actually created the backdrop for reform policies, succeeded at least partially in the fulfilment of such political ambitions. However, experts from less prestigious institutions that remained in the shadow of the ČSAV had more difficulty asserting themselves.

Reform-oriented expertise was inclined towards technocratic solutions. This was expressed, for example, in research on management. Management studies scholars referenced the successful application of management methods in Western Europe and the USA, arguing that strengthening the managerial class is necessary for successful economic reform. Managers were meant to become "socialist entrepreneurs", who had the power to run enterprises as for-profit businesses. They were no longer simply the executors of instructions from the planning centre but heads of enterprises, who were to use all their knowledge and skills without restrictive control from superior bureau-

33 Khrushchev summarised this political programme in his speech at the 22nd Congress of the Communist Party in October 1961. See Documents of the 22nd Congress of the CPSU - Volume I., Report of the Central Committee of the CPSU to the 22nd Congress of the Communist Party of the Soviet Union Delivered by $N$. S. Khrushchev, October 17, 1961. New York : Crosscurrents Press, 1961. An example of a discussion of the importance of science for the future of socialism is the book Věda a naše současnost [Science and Our Present], containing contributions of important representatives of Czechoslovak academia: biochemist and ČSAV chairman František Šorm, microbiologist Ivan Málek and philosophers Radovan Richta and Ladislav Tondl. See Věda a naše současnost. Praha : Academia, 1969. For the ideas of post-industrial socialism and communist techno-optimism, see Civilizace na rozcestí [Civilization at a Crossroads], prepared by Radovan Richta and his research team (first published in 1966). For an English translation of the third extended edition, see RICHTA, Radovan et al. Civilization at the Crossroads: Social and Human Implications of the Scientific and Technological Revolution. Prague : International Arts and Sciences Press, 1969. From period considerations on the social role of the science, see ŠORM, František. Věda v socialistické společnosti: (poznámky k otázkám společenské funkce vědy, rízení a organizace vědecké práce). Praha: Academia, 1967; and MÁLEK, Ivan. Otevřené otázky naší vědy: boj nového se starým v dnešní naší vědě. 2. [část], Úvaha. Praha: Academia, 1966.

34 Programme materials of the congress, see 13. sjezd Komunistické strany Československa: Praha, 31. 5.4. 6. 1966. Praha: Svoboda, 1966.

35 The Action Programme of the Communist Party of Czechoslovakia. In REMINGTON, Robin Alison (ed.) Winter in Prague: Documents on Czechoslovak Communism in Crisis. Cambridge, MA : MIT Press, 1969, pp. 88-136.

36 An extensive debate among economists on this issue was published in 1966 in the journal Ekonomická revue: Od nivelizace k denivelizaci. In Ekonomická revue, 1966, Vol. 1, No. 6, pp. 276-287 and no. 7, pp. 313-321. 
crats. On a more theoretical level, the "scientific and technological revolution" theory mirrored these technocratic tendencies, linking the future of socialism with the development of science and technology. Radovan Richta and his colleagues characterised scientists and experts as the most important initiators of the development towards communism. In this position, they were poised to replace the working class. Post-industrial socialism demanded a new power hierarchy in which a government of experts would replace the government of the working class and party apparatchiks. ${ }^{37}$

The newly acquired, professional self-confidence was also evident in more intensive communication across the "Iron Curtain". Leading Czechoslovak experts and thinkers, such as Radovan Richta and Ota Šik, considered the "new Czechoslovak model of socialism" as an alternative not only to Stalinism, but also to liberal capitalism. According to them, this was a model of socialism suitable for export to the West. Reform communist historians Miloš Hájek and Oldřich Janeček discussed the "Czechoslovak road to socialism" from 1945 to 1948, which they considered an attempt at a democratic way of building a socialist system. Unlike the Soviet and Yugoslav revolutions, which came from revolutionary violence and corresponded to the conditions of agrarian economies, the "Czechoslovak road to socialism" could serve as an example for similar socialist revolutions in the West. This was a revolution based not on a violent seizure of power, but on the building of social and cultural hegemony, just as Antonio Gramsci had imagined revolution in advanced industrial countries. ${ }^{38}$ If such a vision of the "Czechoslovak road to socialism" was the basis of reform, the model of socialism that emerged from it was to be the foreshadowing of a global transformation to democratic socialism as a third way, between liberal capitalism and Soviet communism. ${ }^{39}$ Reform-oriented experts considered themselves to be the creators of the socialism of the future, which was to overtake capitalism in terms of economic justice, technological development and the scope of citizen participation in the governance.

The self-assurance of these experts could also be seen in their efforts to change the rules by which the socialist state operated. Economic reform based on the concept of market socialism sought to reconfigure the relationship between the state and the economy, which required experimentation with management and planning as well as with employee self-government. An entirely untested experiment in the context of the whole Eastern Bloc was reform of the political system, demanding democratisation through the enabling of political competition. Although Czechoslovak reformists realised only the federalisation of the country, the reform efforts of legal and political scientists showed the extent of their experimentation with the institutions and mechanisms of the socialist state.

37 SOMMER, Vítězslav. "Are we still behaving as revolutionaries?”: Radovan Richta, Theory of Revolution and Dilemmas of Reform Communism in Czechoslovakia. In Studies in East European Thought, 2017, Vol. 69, No. 1, pp. 93-110.

38 JANEČEK, Oldřich. Dílo Antonia Gramsciho jako metodologické východisko ke zkoumání našeho přístupu k socialistické revoluci, ke zkoumání dějin čs. odboje. In Historie a vojenství, 1964, Vol. 13, No. 5, pp. 705-735.

39 JANEČEK, Oldřich. Kdy u nás začala socialistická revoluce? In LACINA, Vlastislav (ed.) Československá revoluce v letech 1944-1948. Sborník príspěvkủ z konference historiků k 20. výročí osvobození ČSSR. Praha : Academia, 1966, pp. 96-100; and HÁJEK, Miloš. I socialismus má své vývojové etapy. In Nová mysl, 1969, Vol. 23, No. 2, pp. 135-136. 


\section{Experts Under the "Consolidation" (1970s and 1980s)}

The Warsaw Pact invasion of Czechoslovakia in August 1968 and the political changes that followed, known as "consolidation" or "normalization", ended the era of reforms. Unlike the previous period, when social scientists and experts linked Marxism with different intellectual traditions, "consolidation" ended any experimentation and declared allegiance to a "pure" Marxism-Leninism. Another change was stricter institutional control, which punished the reformists by transferring them to less prestigious institutions, reassigning them to less important positions, banning from publishing completely, or outright dismissal from employment with no opportunity to pursue their professional careers. Some prominent reform-oriented scholars and a number of economists, including Ota Šik, emigrated to the West. Many experts retreated from their previously held reformist positions and adapted to the demands of "normalization". The most significant example of such a pragmatic solution is that of Radovan Richta, who in 1969 publicly renounced the most pro-reform aspects of the "scientific and technological revolution" theory and thus ensured the continuation of his career as director of the most important social scientific institution in the country. ${ }^{40}$

"Normalizers" labelled reform communism as an ideological deviation from MarxismLeninism. As such, the experts had to more cautiously anticipate the political implications of their research. Attempts at achieving any greater independence from political institutions also ended. The expert was no longer to be an autonomous co-creator of policies, but a subordinated worker in centralised decision-making. The new consolidation regime demanded a large-scale deployment of expertise, but allocated service positions in the power hierarchy to experts and subjected them to strict political control. Cold War rhetoric, which mobilised against "bourgeois theories" and called for a clear demarcation between Marxist-Leninist scholarship and its Western counterparts, also returned to the language of the social sciences.

"Consolidated" socialism continued to employ an extensive base of experts, but applied stricter supervision, not only over the experts, but over all aspects of society. In the case of economic policies, KSČ leadership characterised the development of the 1960s as the subordination of properly prepared economic reform to the political interests of "right-wing revisionists". In December 1970, resolution of the Plenum of the Central Committee of the KSČ declared a return to the policy of "improving the socialist system of economic management". It was ratified in 1965 and confirmed by the 13th Congress of the KSČ in 1966. An essential part of the regime's "consolidation" policy was removal of the "revisionist sediments" that had "deformed" reforms in the second half of the 1960s. ${ }^{41}$ According to party resolutions and expert analyses from the early 1970s, the "revisionists" had misused economic reform to pursue anti-socialist goals - they excessively criticised central planning, undermined the socialist concept of ownership, sought to make the market the primary mechanism of economic governance, intend-

40 This was the Institute of Philosophy and Sociology of the ČSAV, which was established during the course of the "consolidation" by merging the Institute of Sociology and the Institute of Philosophy of the ČSAV. Richta remained director of the institute until his death in 1983.

41 FREMER, Miloslav - KOLÁČEK, František - ŠEDIVEC, Václav. Některé rysy revizionismu v politické ekonomii v druhé polovinè 60. let $v$ ČSSR. Praha : Svoboda, 1973, pp. 12-13. 
ed to convert enterprises into market entities and analysed capitalism uncritically. ${ }^{42}$ The reformists allegedly aimed to rebuild the socialist economy into a social-market economy in the style of Western European countries. The result, according to the "normalizers", was not only the politicisation of reforms, but also the destabilisation of the Czechoslovak economy.

The new party elite did not require economic experts to return to Stalinist economics, but preferred that they continue in their expertise, though without experimentation and reformist political demands. Experts deprived of direct political influence were to pragmatically resolve operational issues and respect the authority of central institutions as all modifications to economic policies were subject to the control of ministries, planning authorities and state or party leadership. Experts operated in a centralist and bureaucratic system, in which any change required a blessing "from above" and careful manoeuvring between the snares put to them by planning, ministerial, corporate or party bureaucracy in pursuit of their own power interests.

The experts were not expected to reform socialism, only to maintain and stabilise the system so that it functioned without any disruption to the power relations established after the fall of the Prague Spring. Expertise without real decision-making power was now in the hands of political elites and bureaucrats as an instrument for maintaining political and social stability. The experts were obliged to respect the depoliticised nature of the public sphere while managing the country's economic and social development as mere technical problems. In the first half of the 1970s, Czechoslovakia could thus appear as an island of stability in a turbulent world compared with the West or neighbouring Poland. While capitalism fell into economic crisis, Czechoslovakia's economy could temporarily boast of modest growth, full employment and generous social policies. There were no strikes in the country, demonstrations or even political disputes over systemic questions. The "normalization" leadership controlled the state and economy technocratically; they did not have to face serious ideological challenges or social pressure "from below" in the form of an active workers' movement for example. Prior to the Charter 77 initiative, political opposition remained significantly suppressed. Experts were not to meddle in political decision-making but to come up with ways of solving, for example, economic, welfare and urban planning issues or environmental problems.

Individual experts were required to be disciplined, cautious and pragmatic, resigning themselves to unambitious proposals. When confronting the state and party apparatus, it was best to proceed with baby steps towards minor gains and partial victories. Small, informal collectives arose that promoted professional standards and were sceptical of ideological demands. Non-conformist professional activities took place within these groups, often going beyond the typically mediocre professional competencies of the "consolidated" social sciences. Falling into pragmatic conformism and cynical resignation was also a danger for the experts. The politically and ideologically controlled expertise needed to complete a lot of pointless work, supplying the bureaucratic apparatus with formal research reports, for example. If experts wanted to take on something new and politically nonconformist, it required a great deal of commitment, influential 
allies, the ability to negotiate and a willingness not only to take risks, but also to make morally and professionally troubling compromises. ${ }^{43}$

The social sciences found themselves in greater international isolation after 1968 as "normalization" limited contact with the West. Economists, sociologists and other researchers were obliged to work more with theories and methods anchored in MarxismLeninism, and in particular, with the results of Soviet scholarship. During this period, the social sciences partially lost the ability to operate internationally, across the "Iron Curtain". The time when Czechoslovakia could boast of social scientific knowledge intended for a global public, such as the reformist theory of "the scientific and technological revolution" or the economics of market socialism and the "third way", was now gone. Experts were supposed to deal with domestic problems, especially those related to the "national economy", and potentially to solve, along with colleagues from the USSR, East Germany or Poland, issues specific to socialist countries. The reputation earned in the 1960s dissipated as the social sciences were no longer of interest on the international level. Inside the academic community and in the expert milieus, a feeling of falling behind the West began to grow. Following a brief period of international fame in the second half of the 1960s, Czechoslovakia withdrew to a position in the social scientific periphery, with normalization delivering a serious blow to expert confidence. Here in this moment, it is possible to locate the origins of intellectual selfmarginalisation, which remains a significant characteristic of the social sciences in Central and Eastern Europe.

Expertise was preferentially focused on questions associated with operation of the centrally planned economy. For example, economists, sociologists and management studies scholars did research in social planning, which hoped to apply the processes of economic planning in the management of society. ${ }^{44}$ Social planning studied the role of work collectives and enterprises in welfare policies and created rules for developing communal strategies for individual enterprises. It followed the corporatisation of social policy in the 1970s, i.e. the partial transfer of welfare expenses to enterprises in order to care for the essential social needs of their employees (health care, housing, catering, education, leisure, cultural activities). In the long run, the aim of this welfare arrangement was to deepen the socialist character of society. ${ }^{45}$ Social planning was a notably

43 The institutional history of social scientific expertise in the 1970s and 1980s has not yet received sufficient attention. Thus far, the only case study on this topic is from NEŠPOR, Zdeněk. „Šedá zóna“ v éře tzv. normalizace: Dům techniky ČSVTS Pardubice v dějinách české sociologie. In Sociologický časopis / Czech Sociological Review, 2014, Vol. 50, No. 1, pp. 107-30. For an analysis of the functioning of censorship and its impact on the academic community, see OATES-INDRUCHOVA, Libora. Censorship in Czech and Hungarian Academic Publishing 1969-89: Snakes and Ladders. London : Bloomsbury Academic, 2020. On the writing of the social and cultural history of expert communities in the "normalization" era, see SOMMER, Vítězslav. Průvodce světem socialistické technokracie. Prozaická tvorba Stanislava Váchy jako historický pramen. In Střed, 2020, Vol. 12, No. 1, pp. 98-123.

44 For the development of social planning in Czechoslovakia, see SOMMER et al. 2019, pp. 101-106; and SOMMER, Vítězslav. Managing Socialist Industrialism: Czechoslovak Management Studies in the 1960s and 1970s. In CHRISTIAN, Michel - KOTT, Sandrine - MATĚJKA Ondřej (eds.) Planning in Cold War Europe: Competition, Cooperation, Circulations (1950s-1970s). Berlin; Boston : De Gruyter, 2018, pp. 237-260. From the large amount of period literature on social planning, see, e.g., STÍBALOVÁ, Běla. Sociální plánování v ČSSR a SSSR. Praha : ÚVTEI, 1976; BAUEROVÁ, Jaroslava et al. O sociálním plánování. Praha : Práce, 1972; KUTTA, František et al. Teorie a praxe sociálního plánování a programování v ČSSR. Praha : Svoboda, 1980.

45 For an analysis of the corporatisation of the welfare state in Czechoslovakia, see RÁKOSNÍK, Jakub - TOMEŠ, Igor et al. Sociální stát v Ceskoslovensku. Právně-institucionální vývoj v letech 1918-1992. Praha : Auditorium, 2012, pp. 170-191. 
technocratic discipline, which applied economic planning methods to welfare policies and social engineering.

The sociology of the "socialist way of life" or "socialist lifestyle" was closely associated with social planning. ${ }^{46}$ Czechoslovak "consolidation" attempted to establish a new culture of everyday life reflected in the value system, cultural and consumer preferences, and leisure-time activities. The establishment of a "socialist lifestyle" would be the final result of welfare policies introduced by social planning. Sociologists who adopted the "socialist lifestyle" concept from the USSR in the early 1970s claimed that, unlike capitalist society which was disintegrating under the weight of class conflicts and cultural fragmentation, socialist society was characterised by a high level of class as well as cultural and ideological uniformity. This homogeneous social order was therefore to create a homogeneous lifestyle. Through planned social and cultural policies, plus the suppression of social and cultural phenomena that deviated from the normative ideas about a "socialist way of life", every Czechoslovak citizen was to gradually adopt an obligatory lifestyle.

An overall emphasis on economic issues influenced other areas of expertise. In the 1970s, research on the organisation of production, the labour force and the working environment was among the central topics of Czechoslovak sociology. ${ }^{47}$ Expertise focused on computer technologies, with automation closely tied to the study of economic planning. Computers were thought to enable the smooth flow of information in the planning system, which would permit more flexible and efficient management of the economy from a single centre. ${ }^{48}$ The introduction of computers was intended to lead to the building of so-called automated control systems in enterprises and the central level. ${ }^{49}$ Moreover, the logic of economic development was essential for forecasting expertise (prognostika). The aim was to predict long-term economic and social trends and create a complex system of forecasting that would serve central planning. ${ }^{50}$ In short, after 1968, the experts were supposed to help sustain technocratic authoritarianism and

46 For the most important texts of the sociology of the socialist lifestyle, see VEČERNÍK, Jiří. K problému konceptualizace socialistického životního stylu. In Sociologický časopis, 1972, Vol. 8, No. 3, pp. 249-260; FILIPCOVÁ, Blanka. Morální norma a jednání v utváření socialistického způsobu života. In Filosofický časopis, 1976, Vol. 24, No. 1, pp. 35-41; FILIPEC, Jindřich - FILIPCOVÁ, Blanka. Socialistický humanismus a životní způsob. Socialistický způsob života jako objekt poznání a řízení. In Filosofický časopis, 1976, Vol. 24, No. 6, pp. 940-960; FILIPCOVÁ, Blanka - FILIPEC, Jindřich. Ruznoběžky života. Zápas o socialistický životní zpưsob. Praha : Svoboda, 1976; FILIPEC, Jindřich - FILIPCOVÁ, Blanka. Socialistický způsob života - skutečnost $i$ program. Praha : Horizont, 1980. For a brief outline of the theory of the "socialist lifestyle" in Czechoslovakia, see SOMMER, Vítězslav. The Last Battlefield of the Cold War: From Reform-Oriented Leisure Studies to Sociological Research on the "Socialist Lifestyle" in Czechoslovakia 1950s-1989. In SOLOVEY, Mark DAYÉ, Christian (eds.) Cold War Social Science: Transnational Entanglements. Cham : Palgrave Macmillan, 2021, pp. 225-254.

47 KOHOUT Jaroslav. Plánování sociálního rozvoje kolektivů pracujících podniku - současná teorie a praxe v ČSSR. In Sociologický časopis, 1973, Vol. 9, No. 6, pp. 624-632; KOHOUT Jaroslav. Plánování sociálního rozvoje kolektivu socialistického podniku a úkoly podnikového sociologa. In Sociologický časopis, 1973, Vol. 9, No. 2, pp. 155-160; KOHOUT Jaroslav. Sociální analýza a řízení socialistického podniku: Vznik - pojetí aplikace. Praha : Práce, 1976. For labour force research, see KALINOVÁ, Lenka. Máme nedostatek pracovních sil? Praha : Svoboda, 1979.

48 For example, see MARKUŠ, Jozef. Teória optimálneho plánovania a fungovania socialistickej ekonomiky: (vývin a otvorené otázky). Bratislava : VEDA, 1978.

49 The idea of automated control systems was summed up by BUKÁČEK, Zdeněk - MAZEL, Bohumil. Metodika projektování ASŘ: Úvod do projektování automatizovaných systémů rízení. Praha : Ústav technických a ekonomických služeb, 1974. See also SOMMER et al. 2019, pp. 106-110.

50 SOMMER, Vítězslav. Forecasting the Post-Socialist Future: Prognostika in Late Socialist Czechoslovakia, 1970-1989. In ANDERSSON, Jenny - RINDZEVIČIÜTĖ, Eglè (eds.) The Struggle for the Long-Term in Transnational Science and Politics: Forging the Future. London; New York: Routledge, 2015, pp. 144-168. 
the so-called scientific management of socialist society meant using available scientific knowledge for centralised control of social and economic processes. ${ }^{51}$

\section{Conclusion}

Vannevar Bush's report summarised the hopes which political elites of the West, the East and the Global South put into the alliance of the state and expertise. Forty years of the Cold War brought the development of technologies and infrastructures that would not have been possible without such close cooperation. However, at the end of the era, there was notable scepticism towards the idea that scientific knowledge and expert governance would solve all of humanity's problems. The failure of post-war modernist ideas of progress was especially visible in the Eastern Bloc where it was evident that the combination of an authoritarian state, a centrally planned economy and governing through expertise had not led to general prosperity or social equality.

The 1980s bore the signs of deepening economic and environmental problems in Czechoslovakia. The consolidation regime was losing its fragile social support, which manifested not only in the rising activities of the political opposition, but also in the local version of Perestroika (Czech: přestavba). Despite Czechoslovak political elites being more cautious and ideologically conservative than Mikhail Gorbachev and his collaborators in the USSR, public debates about the current state and the future of socialism showed the degree of dissatisfaction in society with developments after 1968. The rhetoric of Perestroika emphasised a necessity of public debate and political changes. Although calls for openness and economic and political reconstruction by party elites were often only formal statements, it was enough to break down the ideological foundations of "normalization". Moreover, the economic and environmental crises represented urgent problems that needed to be addressed and the experts again were supposed to help. Efforts to save socialism brought the further mobilisation of expertise and freed it, to certain extent, from its strict political and ideological control.

However, the general crisis of state socialism also led to a crisis of expertise. There was not only a growing disillusionment with the state of affairs among experts, they also rediscovered a willingness to express criticism and search for an escape from the prevailing intellectual and political conformity. Economists and sociologists began to complain about the technocratic clumsiness and ideological limitations of the political and economic system, in which it was very difficult to promote any change or even simply discuss unorthodox solutions to economic and social problems. Although experts criticized the inefficiency of central planning or environmental devastation even before Perestroika, their opinions, supported in their view by scientific facts, could not penetrate the bureaucratic machinery of the state and failed to arouse the interest of party elites. The experts warned of increasing problems and offered solutions, though at the same time were aware of their limited power in comparison to influential bureaucrats and officials. Dissatisfaction with the governance by state and party elites was shared by the experts, who otherwise had very different theoretical backgrounds and political beliefs: economists looking to the legacy of the Prague Spring, their colleagues betting

51 The Soviet concept of scientific management of socialist society in the era of "developed socialism" was introduced by AFANASJEV, Viktor Grigorjevič. Vědecké řízení společnosti. Praha : SPN, 1977. 
on the possibilities of the free market, sociologists calling for the renewal of civil society, and even ideologues close to party leadership thinking about the gradual disintegration of the Communist Party's "leading role". The latter knew well that the KSČ was unable to handle the situation and due to economic difficulties, the grey economy and pervasive corruption, it was losing any remnants of support in society. The consensus among the experts was that the crisis is a reality, it needs to be resolved and that it is they themselves who know how to do it.

Disappointment from their weak position in the hierarchy of power was entwined with notions of their own social importance. Once Perestroika, like the Prague Spring, relaxed control over public debate and identified expertise and diligence as the means of achieving necessary changes, another stellar hour for the experts came again, twenty years later, when the theoretical paradigm and ideological dogma that underpinned the policy of expertise after 1968 had collapsed. Economists increasingly and more openly promoted reforms based on introducing a market economy, thus paving the way for a later resurgence of capitalism. At the lower levels of economic planning, the problems of enterprise management and the call for an autonomous position not only for enterprises but managers too, was a central topic. However, as in the 1960s, the idea of employee self-government resonated..$^{52}$ Sociologists began to write more critically about social problems and opened a debate on the technocratic trap that their field had fallen into in the 1970s. ${ }^{53}$ The state of the environment also became one of the main discussions at the end of the decade, not only among experts, but also in the broader public. $^{54}$

The relationship of state socialism to social scientific expertise seems to be a development from the "expertisation" of the social sciences in the second half of the 1950s to the experiments and innovations of the 1960s. After 1968, expertise was subordinated to the pragmatic needs of the consolidation regime. Thus, Perestroika left the impression that the experts would be taken back to 1968 by a time machine. The end of the 1980s, however, brought a different politics of expertise than the 1960s. Following the activities of experts in the years of "normalization", the Perestroika expertise focused primarily on issues related to the economy. Pragmatic economic reductionism so typical of expert activities after 1968 influenced expertise of the late 1980s and early 1990s. It is possible to see a similar continuity in the focus on day-to-day economic issues and the underestimation of interest in the long-term development of the state and society. Expert projects transcending the narrow economic perspective did not attain privi-

52 The debates on economic transformation are analysed by RAMEŠ, Václav. Trh bez prívlastkü. Spory o podobu vlastnické transformace v porevolučním Československu. Praha : ÚSD AV ČR, 2021.

53 Critical texts by Slovak sociologists from the late 1980s in particular addressed this topic: FRIČ, Pavol GÁL, Fedor - DIANIŠKA, Ivan. Profesiová orientácia sociológa vo svetle spoločenských očakávaní. In Sociológia, 1988, Vol. 20, No. 1, pp. 71-80; BÚTOROVÁ, Zora - DIANIŠKA, Ivan. Samoregulácia vedeckého spoločenstva. In Sociológia, 1988, Vol. 20, No. 2, pp. 141-155 and KRIVÝ, Vladimír. Sociotechnika: Možnosti a hranice. In Sociológia, 1988, Vol. 20, No. 4, pp. 417-425. In the Czech part of Czechoslovakia, where stricter political control of the social sciences than in Slovakia predominated, the platform for critical sociology was primarily the samizdat journal Sociologický obzor, published between 1987 and 1989 and largely written by sociologists Josef Alan and Miloslav Petrusek. The journal's archive is available on the Internet: http://scriptum.cz/cs/periodika/sociologicky-obzor

54 For the debate on the environment, see VANĚK, Miroslav. Nedalo se tady dýchat: ekologie v českých zemích $v$ letech 1968 až 1989. Praha : Ústav pro soudobé dějiny AV ČR v nakl. Maxdorf, 1996; and JEHLICKA, Petr SMITH, Joe. Trampové, př́rodovědci a brontosauři. Předlistopadová zkušenost českého environmentálního hnutí jako předzvěst ekologické modernizace. In Soudobé dějiny, 2017, Vol. 24, No. 1-2, pp. 78-101. 
leged positions and only rarely offered a more comprehensive image of social and political change. ${ }^{55}$ The mainstream of expertise prioritized economic reform, on which everything else was to be based.

The role of expertise in the first years post-socialism is still awaiting a systematic historiographical elaboration. ${ }^{56}$ Current research indicates that the building of capitalism was based, to a great measure, on the primacy of the economy. That is, on an idea close to simplified Marxism; the transformation of the economic base, which is the main task of experts and politicians, will be the starting point for social and political change. Post-socialist experts therefore followed the economism of the consolidation regime. Further research will show to what extent these preliminary conclusions can be revised thanks to a more thorough analysis of the activities of legislative experts, experts working in the international NGO sector focused on building civil society, environmentalists in state institutions and NGOs, sociologists mapping societies in transition and experts based in various European institutions and supranational organizations, among others. The challenge for future historiography is to validate or deny the hypothesis that the economic reductionism of "normalization" predetermined the form of expert interventions in the period of post-socialist transformation.

55 An important exception was the comprehensive proposal for "green" political and economic reforms presented in 1989 by cybernetician and environmentalist Josef Vavroušek. See VAVROUŠEK, Josef. Životní prostředí a seberízení společnosti. Praha : Institut řízení, 1990.

56 For the first major contributions to the topic, see KOPEČEK, Michal (ed.) Architekti dlouhé změny: expertní kořeny postsocialismu v Československu. Praha : Argo, 2019.

\section{Cite:}

SOMMER, Vítězslav. An Unequal Alliance: Social Scientists as Experts in Socialist Czechoslovakia. In Forum Historiae, 2021, Vol. 15, No. 2, pp. 51-68. ISSN 1337-6861. DOI: https://doi.org/10.31577/forhist.2021.15.2.5

Vítězslav Sommer

Ústav pro soudobé dějiny AV ČR, v.v.i.

Puškinovo nám. 9

16000 Praha 6

email: sommer@usd.cas.cz

https://orcid.org/0000-0002-5503-9151 